\title{
PERAN KODIM 0506/TANGERANG DALAM PEMBERDAYAAN WILAYAH PERTAHANAN GUNA MENGAMANKAN PILKADA SERENTAK TAHUN 2020
}

\author{
Agus Subagyo ${ }^{1}$ Agustina Setiawan ${ }^{2}$ \\ Iing Nurdin ${ }^{3}$ Bayu Septiansyah ${ }^{4}$ \\ Universitas Jenderal Achmad Yani
}

\begin{abstract}
Abstrak
Tujuan dalam penelitian ini adalah Untuk mengetahui dan mendeskripsikan Peran Kodim 0506/Tangerang Dalam Pemberdayaan Wilayah Pertahanan Guna Mengamankan Pilkada Serentak Tahun 2020 dan Untuk mendeskripsikan Peran Kodim 0506/Tangerang Guna Mengamankan Pilkada Serentak Tahun 2020. Metode dalam penelitian ini menggunakan penelitian kualitatif, dalam penelitian kualitatif menggunakan metode kualitatif yaitu pengamatan, wawancara dan penelaahan dokumen. Berdasarkan hasil penelitan dapat di simpulkan bahwa Kesiapan Kodim 0506/Tangerang dalam pemberdayaan wilayah pertahanan guna mengamankan pilkada serentak, bisa terlihat dari Personil yang berkualitas dan professional dalam bidangnya. Anggaran yang ada sudah cukup memadai meskipun terkadang mendapat sedikit kendala pada saat penyelenggaraannya. Soliditas dan Sinergitas Kodim, Polres dan Pemerintah Daerah dalam Pemberdayaan Wilayah Pertahanan Guna Mengamankan Pilkada Serentak terjalin sangat baik.
\end{abstract}

Kata kunci: Peran, Kodim, Pilkada

\begin{abstract}
The purpose of this research is to know and describe the role of Kodim $0506 /$ Tangerang in Empowerment of Defense Areas to Secure the 2020 Regional Head Elections and to describe the Role of Kodim 0506 / Tangerang in Securing the 2020 Regional Head Elections. The method in this study uses qualitative research in qualitative research. using qualitative methods, namely observation, interviews and document review. Based on the results of the research, it can be concluded that the readiness of Kodim 0506 / Tangerang in empowering defense areas to secure simultaneous regional elections, can be seen from qualified and professional personnel in their fields. The existing budget is quite adequate, although sometimes it gets a few obstacles when its implementation. Solidity and Synergy of Kodim, Polres and Regional Government in Empowerment of Defense Areas to Secure Simultaneous Pilkada are very well established.
\end{abstract}

Keywords: Role, Kodim, Pilkada 


\section{PENDAHULUAN}

Pemilihan kepala daerah merupakan proses pemilihan orang-orang untuk mengisi jabatan politik kepala daerah dan wakil kepala daerah. Para pemilih dalam pemilihan kepala daerah disebut juga konstituen dan kepada merekalah para peserta pemilihan kepala daerah menawarkan janji-janji dan program-programnya pada masa kampanye. Bangsa Indonesia menganut system demokrasi dimana pemerintah daerah dipilih melalui suatu proses pesta demokrasi yang dinamakan pemilihan kepala daerah. Pemilihan kepala daerah secara langsung akan berlangsung dengan optimal apabila didukung oleh penyelenggaraan pemilihan kepala daerah yang kondusif baik para penyelenggaranya maupun peserta dan masyarakatnya.

Indonesia akan menyelenggarakan Pemilihan Kepala Daerah Serentak pada Desember tahun 2020 ini. Kota Tangerang Selatan adalah salah satu daerah yang bakal menyelenggarakan pemilihan kepala daerah tahun ini. Pertarungan relatif lebih cair karena petahana, Airi Rachmi Diany tak bisa lagi mencalonkan karena sudah dua periode menjabat. Salah satu yang menarik di Pilkada Tangsel adalah perebutan kekuasan dengan sentimen dinasti politik. Setidaknya ada tiga nama yang terkait dengan dinasti. Airin sendiri adalah bagian dari isu dinasti politik karena ipar dari mantan Gubernur Banten Ratu Atut Chosiyah yang sejumlah anggota keluarganya masih berkuasa di beberapa daerah di provinsi paling barat Jawa ini.Tiga nama kandidat bakal calon wali kota di Tangsel yang terkait dengan dinasti adalah putri Wakil Presiden Ma'ruf Amin, Siti Nur Azizah; keponakan Prabowo Subianto, Rahayu Saraswati; dan anak Bupati Serang Ratu Tatu Chasanah Pilar Saga Ichsan yang masih kerabat Ratu Atut.

Untuk mewujudkan penyelenggaraan pilkada serentak 2020 yang aman dan kondusif maka disarankan agar penyelenggara, pengawas, dan aparat keamanan yang bertugas secara umum melakukan deteksi dini atas potensi-potensi ancaman pilkada serentak yang telah diuraikan di atas. Peran intelijen sangat besar dalam melakukan deteksi dini, dan membuat pemetaan pihak-pihak yang mempunyai niat, kemampuan, dan kesempatan untuk melakukan ancaman. Dengan adanya peta ancaman maka pencegahan akan lebih mudah dilakukan. Selanjutnya adalah 
menutup semua celah-celah kerawanan agar tidak menjadi jalan bagi terjadinya ancaman. Ketertiban administrasi, pengawasan, penegakan hukum, dan jaminan netralitas ASN, TNI dan Polri harus dilakukan. Masyarakat harus diyakinkan bahwa pemicu kerawanan tersebut sudah diatasi dan tidak ada pada penyelenggaraan pilkada serentak 2020. Langkah-langkah prevention, preparation, response and recovery perlu disiapkan untuk mencegah, menghadapi, dan memulihkan situasi atas ancaman Pilkada serentak. Kerja sama antarlembaga pemerintah seperti KPU, Bawaslu, Polri, BIN, TNI, Pemprov, dan Pemda perlu dilakukan untuk menyusun langkah-langkah tersebut sehingga ketika terjadi ancaman dapat ditangani dengan lebih cepat.

Kesiapan aparat keamanan dinilai sangat penting agar pelaksanaan pemilihan kepala daerah tahun 2020 dapat berjalan dengan lancar tanpa adanya gangguan keamanan. Keterlibatan satkowil dalam mengantisipasi berbagai potensi kerawanan yang akan terjadi menjelang perhelatan pilkada 2020 dan selama penyelenggaraan pilkada menjadi penting. Selain Polri, Satkowil perlu terlibat dalam pemilihan kepala daerah tentunya dalah hal menjaga stabilitas keamanan nasional.

Komandan Kodim dalam hal ini selaku Satkowil yang bertugas membantu memberikan bantuan keamanan kepada pemerintah daerah dan polri dalam pelaksanaan pilkada harus mampu mempetakan daerah-daerah rawan sesuai dengan tugas dan fungsinya, begitu pula dalam hal polri meminta bantuan kepada satkowil dalam rangka pengamanan pilkada, maka tentunya Satkowil harus mempersiapkan diri melalui pembinaan teritoraiallnya untuk dapat memaksimalkan peran bantuan terhadap polri serta mampu pula mengoptimalkan peran forkompinda dalam rangka kerjasama antar lembaga dalam menciptakan situasi yang aman dalam pilkada serentak karena menjadi tugas bersama dan apabila terjadi situasi kondisi konflik maka satkowil perlu menyusun perencanaan dalam rangka peringatan dini, membangun system peringatan dini seperti pemetaan wilayah konflik, penyampaian informasi secara cepat dan akurat, pendidikan dan pelatihan, pemanfaatan media sosial dan pemanfaatan fungsi intelijen.

Dalam kaitan ini, peran Kodim 0506/Tangerang dalam pelaksanaan tugas 
OMSP yang diemban oleh satuan Kodim dan Koramil dalam membantu Polres dan Pemerintah Daerah Kota Tangerang dalam pemberdayaan wilayah pertahanan guna mengamankan pilkada serentak dalam rangka mengawal keberlangsungan pembangunan nasional harus dapat diwujudkan yaitu melalui peran Kodim dalam membantu Pemerintah daerah memberikan bantuan keamanan dalam pelaksanaan pilkada.

Berdasarkan latar belakang masalah maka dilakukan penelitian tentang Peran Kodim 0506/Tangerang Dalam Pemberdayaan Wilayah Pertahanan Guna Mengamankan Pilkada Serentak Tahun 2020. Adapun yang menjadi rumusan masalah dalam penelitian ini ialah Bagaimana Peran Kodim 0506/Tangerang Dalam Pemberdayaan Wilayah Pertahanan Guna Mengamankan Pilkada Serentak Tahun 2020. Adapun tujuan penelitian ini ialah untuk mengetahui dan mendeskripsikan Peran Kodim 0506/Tangerang Dalam Pemberdayaan Wilayah Pertahanan Guna Mengamankan Pilkada Serentak Tahun 2020.

Penelitian ini menggunakan pendekatan deskriptif, proses penelitian kualitatif bersifat seni, dan disebut sebagai metode interpretive karena data hasil penelitian berkenaan dengan interprestasi terhadap data yang ditemukan dilapangan (Sugiyono, 2013). Lebih lanjut (Sugiyono, 2013) menjelaskan bahwa metode penelitian kualitatif digunakan pada kondisi objek yang alamiah dimana peneliti sebagai instrumen kunci. Oleh karena itu penelitian ini lebih menekankan pada metode atau pendekatan penelitian deskriptif kualitatif.

Penelitian yang dilakukan ini bertempat di wilayah Kota Tangerang Selatan. Waktu penelitian adalah rentang waktu yang digunakan selama proses penyusunan proposal hingga penelitian berlangsung, mulai dari tahap persiapan sampai pada tahap penyusunan laporan sesuai dengan sasaran penelitian.

Pengumpulan data dalam penelitian ini peneliti akan menggunakan prosedur pengumpulan data antara lain: Observasi, dengan cara ini peneliti dapat meyakini, dapat melihat dan dapat mengamati sendiri yang kemudian dilanjutkan dengan pencatatan perilaku serta kejadian sebagai mana adanya. Wawancara, melakukan wawancara langsung kepada semua pihak yang berkompoten dalam penelitian ini, agar informasi yang didapatkan tidak meragukan dan dapat 
dipertanggung jawabkan. Dokumentasi, dokumentasi yakni pengumpulan data dari sumber-sumber non visual yakni berupa dokumen-dokumen atau arsip-arsip dan rekaman yang ada relevansinya dengan kebutuhan data yang dibutuhkan peneliti.

\section{PEMBAHASAN}

Sebagaimana dalam kajian penelitian ini yaitu peran Kodim 0506/Tangerang dalam memberikan bantuan terhadap Polri dan pemerintah daerah, khususnya KPUD bahwa peran Kodim 0506/Tangerang dalam penyelenggaraan pilkada serentak tersebut selain merupakan tugas TNI yang telah dijabarkan didalam Undang-undang Nomor 3 Tahun 2003 tentang Pertahanan Negara juga dalam Undang-undang Nomor 4 Tahun 2004 tentang TNI, bahwa TNI apabila diperlukan dapat memberikan bantuan keamanan kepada pemerintah daerah sebagaimana dijelaskan dalam UU Nomor 7 Tahun 2012 dan Peraturan Pemerintah Nomor 2 Tahun 2015, dimana pemerintah daerah dapat meminta bantuan TNI dalam penanganan konflik social setelah berkoordinasi dengan polri.

Upaya pencegahan rawan konflik dilakukan oleh Kodim 0506/Tangerang yaitu melakukan kesiapan personil, kesiapan anggaran, kesiapan sarana dan prasarana serta kesiapan metode atau piranti lunak. Berikutnya Kodim 0506/Tangerang melakukan soliditas dan sinergitas bersama sama dengan Polri dan pemerintah daerah melalui Komunikasi, koordinasi dan kolaborasi. Hal ini dilaksanakan melalui pemetaan terhadap daerah rawan konflik, melakukan perbantuan keamanan kepada polri dan pemda, melakukan pembinaan territorial serta mengoptimalkan pelaksanaan forkompinda sebagai bagian dari tugas TNI AD khususnya satkowil dalam rangka menciptakan kondisi yang kondusif dalam pelaksanaan pilkada 2020 dalam rangka mengawal keberlangsungan pelaksanan pembangunan nasional. Upaya tersebut dilakukan secara sistematis, menyeluruh, efisien dalam penggunaan sumberdaya dan efektif dalam memberikan bantuan kepada polri dan pemerintah daerah. 
Gambar. Model Kerangka Pemikiran

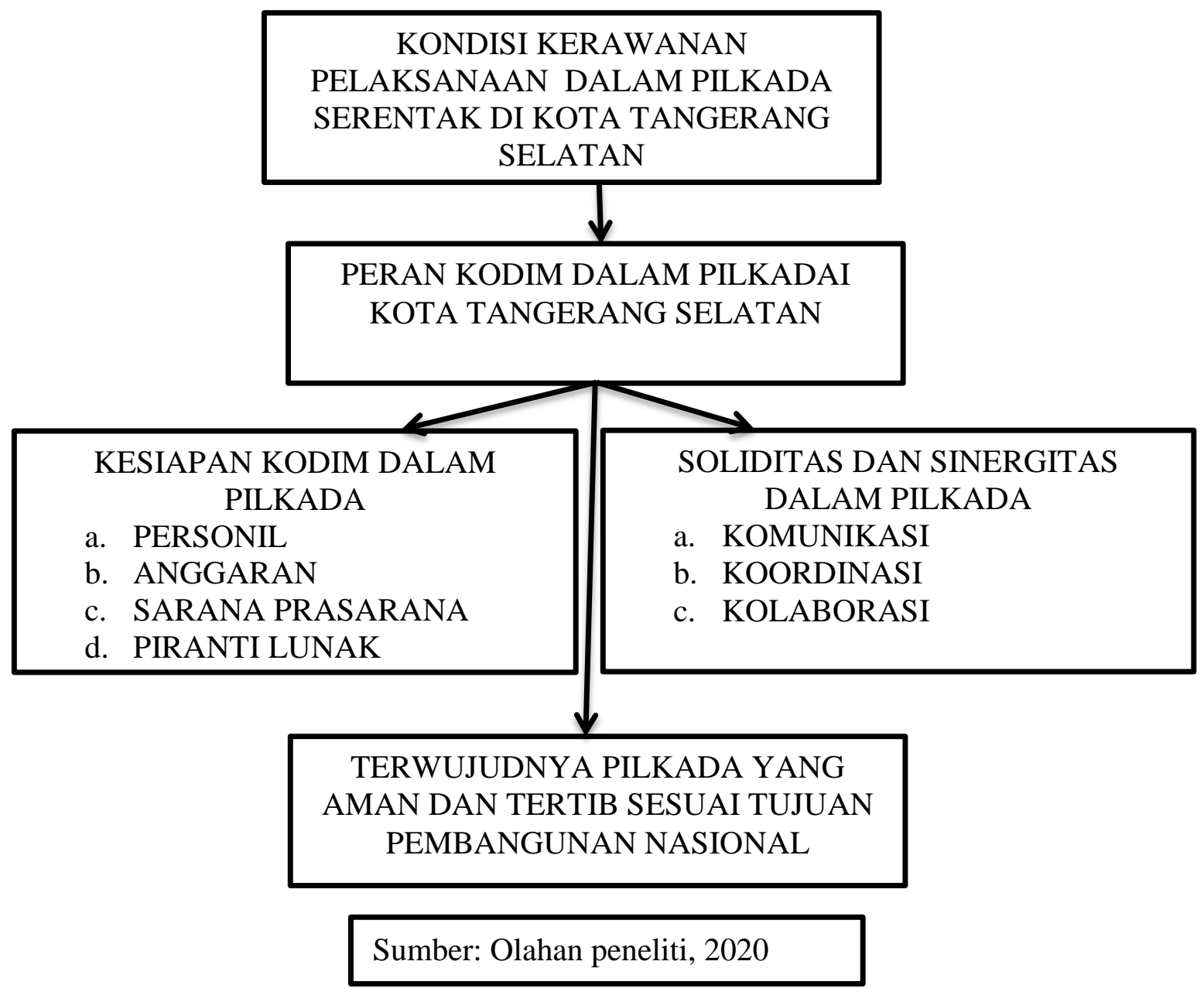

\section{Penyelenggaraan Pilkada KotaTangerang Selatan}

Dalam pelaksanaan pilkada ini KPU meminta dukungan kepada seluruh stakeholder untuk membantu ikut serta menyukseskan Pilkada Tangsel 2020. Seluruh elemen masyarakat, agar bersama-sama menyukseskan Pilkada sehingga berjalan lancar dan baik. KPU optimis partisipasi di Pilkada Tangsel 2020 akan membaik dibandingkan dengan Pilkada 2015 lalu yang tidak sampai 60 persen. Adapun cara yang akan dilakukan oleh KPU Tangsel dalam peningkatan partisipasi yakni, dengan terus melakukan sosialisasi kepada masyarakat. KPU juga belajar dari data lama pemilihan Pilgub Banten 2017, nanti akan dilihat mana yang partisipasinya kurang. Misalnya pada kawasan perumahan elit. Nanti di sana akan kita tingkatkan sosialisasi.

Pilkada tahun 2020 tidak terlepas dari ancaman, adapun pemilahan potensi 
kerawanan Kota Tanggerang selatan telah merunut masalah / potensi ancaman yang akan terjadi di Pilkada Tahun 2020, dijabarkan dalam gambar sebagai berikut:

Gambar. Perkiraan Ancaman Pilkada 2020

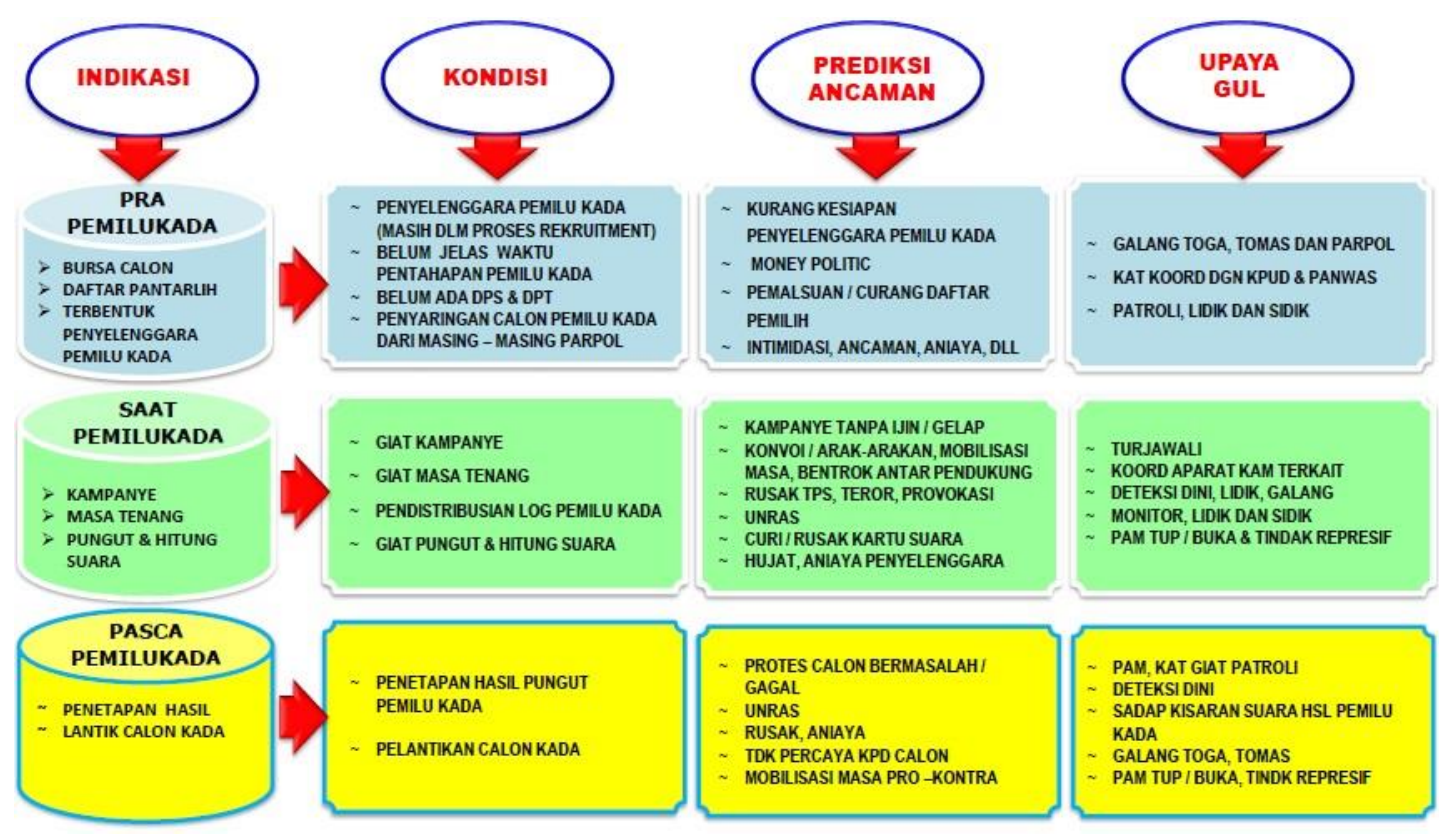

Sumber : Laporan Paparan Renpam Pilkada Kodim 0506/Tangerang Kota Tangsel 2020

Kesiapan Kodim 0506/Tangerang Dalam Pemberdayaan Wilayah Pertahanan

\section{Guna Mengamankan Pilkada Serentak}

Untuk itu peneliti akan menguraikan hasil penelitian dari hasil wawancana dan studi dokumentasi yang berkaitan dengan rumusan masalah yang diuraikan diatas yaitu dijabarkan sebagai berikut :

\section{A. Kesiapan Personil}

Kodim 0506/Tangerang dalam rangka mempersiapkan personil kodim yang siap dalam rangka membantu tugas-tugas pemerintah daerah khsusunya dalam pelaksanaan pilkada serentak di Kota Tangerang Selatan dilaksanakan sesuai petunjuk TNI AD. Personil kodim pada dasarnya telah menetahui dan memahami tugas yang harus dilaksanakan dalam rangka mengsukseskan dan mengawal pilkada serentak tahun 2020 di Kota Tangerang Selatan, hal ini sesuai dengan hasil wawancara dengan Komandan Kodim 0506/Tangerang Kolonel inf Wisnu bahwa : 
"Dalam pelaksanaan pilkada serentak 2020 di Kota Tangerang Selatan pihak kodim dan jajaran kodim sudah siap membantu pemerintah daerah dan polres dalam mengamankan pelaksanaan pilkada”.

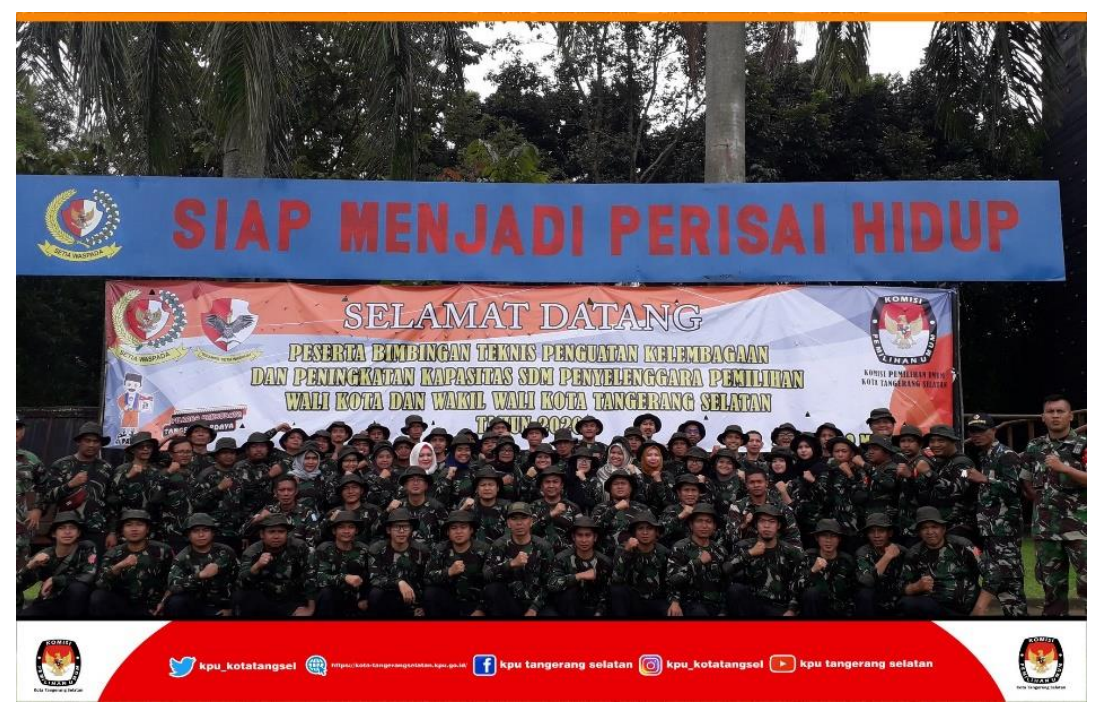

Bahkan kodim setelah mendapatkan informasi tentang jadwal tahapan penyelenggaraan pilkada di Kota Tangerang Selatan langsung mempersiapkan perencanaan dalam rangka pengamanan pilkada serentak di Kota Tangerang Selatan.

Kodim 0506/Tangerang dalam penyiapan personil guna melaksanakan tugas pemberian bantuan terhadap pemerintah daerah dan polres, tentunya diperlukan personil yang mempunyai kualitas dan kuantitas sehingga dalam memberikan bantuan pengamanan dapat dilaksaksanakan dengan secara optimal. Berdasarkan wawancara peneliti dengan Komandan Kodim 0506/Tangerang bahwa :"dalam bidang personil selama ini yang dihadapi oleh kodim dalam kesiapan pengamanan pilkada serentak kota Tangerang Selatan belum mendapatkan kendala".

Secara kuantitas kodim dan jajarannya koramil serta babinsa dirasakan sudah cukup untuk membantuk memberikan pengamanan pilkada. Begitu pula secara kualitas prajurit TNI AD khususnya yang bertugas di kodim, koramil dan babinsa telah dibekali kemampuan dalam rangka melaksanakan tugas tugas OMSP. Profesionalisme TNI AD dan netralitas birokrasi TNI AD tentunya telah ditanamkan dalam diri para 
prajurit sehingga mereka dituntut untuk menjalankan tugas dan patuh terhadap kesatuan serta patuh terhadap NKRI.

\section{B. Kesiapan Anggaran}

Anggaran dalam kesiapan pengamanan pilkada serentak dialokasikan dari anggaran pilkada tahun 2020 yang telah disusun dan dialokasikan oleh pemerintah daerah untuk membiayai penyelenggaraan pilkada melalui Naskah Perjanjian Hibah Daerah (NPHD) dimana untuk kota Tangerang Selatan sebesar Rp. 68 Milyar. Dari anggaran tersebut diantaranya adalah anggaran untuk pengamanan pilkada. Penetapan anggaran keamanan pilkada ditetapkan oleh pemerintah daerah Kota Tangerang Selatan yang diperuntukan bagi TNI dan Polri. Dana tersebut diberikan oleh Pemkot Tangerang Selatan untuk mendukung proses pilkada yang digelar serentak tahun 2020 agar berjalan secara aman, tertib dan lancar.

Dana keamanan tersebut diambilkan dari dana hibah, namun tentunya dalam pencairannya harus menunggu peraturan gubernur, karena untuk mengeluarkan dana hibah harus melalui nota kesepahaman yang resmi. Dengan ditetapkannya anggaran untuk keamanan pilkada oleh pemkot Tangerang Selatan, nantinya dana tersebut akan dihibahkan kepada lembaga vertikal yaitu Polri dan TNI. Dana itu sendiri rencananya dihitung sampai dengan berakhirnya atau terpilihnya walikota yang baru baik itu satu putaran atau dua kali putaran.

Adapun pengelolaan anggaran oleh kodim sebagai dana hibah dari pemerintah daerah sebagaimana wawancara dengan Komandan Kodim Kolonel Inf Wisnu bahwa:

"dalam pengelolaan anggaran pengamanan pilkada serentak oleh dikodim dikelola melalui satker yaitu melalui Korem 052/Wkr. Anggaran yang telah ditetapkan oleh pemerintah daerah dan diberikan untuk hibah pilkada kepada kodim dan polres, dalam pengelolaannya tentunya dilakukan secara transparan dan akuntabel. Kodim mengelola anggaran sesuai dengan peruntukan dalam pengamanan pilkada serentak yang dilaksanakan kota Tangerang Selatan pada tahun 2020”. 
Anggaran yang diberikan pemerintahan daerah yang dialokasikan kepada kodim mampu memenuhi semua kebutuhnan kesiapan pengamanan pilkada serentak, sebagaimana wawancara dengan Komandan Kodim Kolonel Inf Wisnu bahwa: "kodim mampu memprioritaskan kegiatan sesuai dengan anggaran yang telah dialokasikan untuk mememuhi semua kebutuhan kesiapan pengamanan pilkada”.

Namun yang menjadi kendala dalam penyelenggaraan pengamanan pilkada serentak menurut Komandan Kodim Kolonel Inf Wisnu, bahwa: "kurangnya ketepatan waktu dalam menurunkan anggaran sehingga pembelanjaan terhambat oleh kodim dalam kesiapan pengamanan pilkada serentak".

Hal ini tentunya harus menjadi bahan pertimbangan karena pengamanan ini merupakan factor penting dalam menjaga kondusifitas pilkada yang aman, tertib dan lancar. Oleh karena itu diperlukan kecepatan dalam bertindak serta perlunya efektivitas dan prioritas dlam melakukan kegiatan sehingga pilkada berjalan aman, tertib dan lancar. Selama ini kodim masih tergantung anggarannya dari turunnya dana lewat komando atas, tentunya guna efektivitas dan prioritas pelaksanaan pengamanan pilkada serentak, diperlukan adanya alikasi dana khusus bagi kodim untuk pengamanan pilkada sehingga tidak menunggu turunnya dari atas menurut Komandan Kodim. Selama ini dukungan anggaran dapat mencukupi walaupun dengan keterbatasan yang ada. Dana yang diturunkan cukup untuk dipergunakan oleh satuan dalam memelihara kondusifitas pelaksanaan pilkada serentak.

\section{Kesiapan Sarana dan Prasarana}

Pada pelaksanaan pilkada tahun 2020 ini, ancaman konflik bisa saja terjadi, dan bahkan berdasarkan informasi yang terkait dengan penyelenggaraan pilkada oleh Bawaslu Kota Tangerang Selatan disebutkan terdapat beberapa ancaman konflik yang dapat terjadi dalam pelaksanaan pilkada Kota Tangerang Selatan seperti : 
1) Pengancaman

2) Penyebaran Info Bohong (Black Campaign)

3) Money Politic (Serangan Pajar)

4) Pengrusakan/pembakaran

5) Perkelahian antar pendukung/konflik internal peserta pemilu

6) Pemalsuan logistic pemilu

7) Terror

8) Politisasi sara

9) Unjuk rasa (protes)

10) Menghasut untuk tidak menggunakan hak pilih

11) Kerusuhan massa/kontijensi

12) PAM daerah perbatasan

13) Bencana alam

Terkait penyiapan sarana dan prasarana/peralatan kodim dalam pengamanan pilkada serentak 2020 berdasarkan wawancara dengan Komandan Kodim Kolonel Inf Wismu bahwa

"peralatan kodim semuanya sudah stanby di makodim, sedangkan alat komunikasi sudah terbagi di koramil. Alat transfortasi menggunakan inventaris masing-masing koramil dan untuk kendaraan roda 4 stanby di makodim".

Selain alat alat yang sudah stanby di makodim dan koramil, kodim melalui jalur komunikasi antar satuan untuk memberikan informasiinformasi terkait perkembangan kondisi wilayah dalam pelaksanaan pilkada seperti wilayah-wilayah kelurahan dan kecamatan. Masing-masing koramil memberikan informasi kepada dandim terkait perkembangan pengamanan diwilayahnya. Koramil mendapatkan informasi dari masing-masing babinsa. Alat komunikasi ini sebagai sarana yang tepat dan cepat dalam memberikan informasi seputar perkembangan pilkada selalui melalui jalur komunikasi melalui media internet dan juga kodim menggunakan sara media social baik WhatsApp group sebagai sarana kumunikasi maupun melalui WEB Kodim dan Korem serta Kodam. Dengan sarana komunikasi internal kodim dapat mempercepat arus informasi dan dapat dengan segera 
dipersiapkan pencegahannya apabila terjadi ancaman dalam penyelenggaraan pilkada serentak.

\section{Kesiapan Piranti Lunak}

Adapun terkait dengan rencana pengamanan pilkada Kota Tangerang Selatan oleh Kodim 0506/Tangerang tahun 2020 mengacu kepada Undang-undang Nomo 34 tahun 2004 tentang TNI, mengacu pula kepada undang-undang Nomor 23 tahun 2014 tentang Pemerintahan Daerah. Rencana pengamanan tersebut dibuat untuk memberikan gambaran kepada komando atas tentang pelaksanaan kegiatan pengamanan yang akan dilaksanakan dalam rangka pilkada di Kota Tangerang selatan wilayah kodim 0506/Tangerang. Tujuan dibentuknya rencana pengamanan pilkada sebagai bahan masukan dan pedoman/pegawangan bagi unsur bawahan dalam mengatasi segala ancaman dan gangguan guna menjamin kelancaran pelaksanaan kegiatan pilkada kota Tangerang Selatan 2020.

Berdasarkan wawancara yang dilakukan dengan Komandan Kodim Kolonel Inf Wisnu bahwa konsep penyiapan rencana operasi (Renops) kodim dalam pengamanan pilkada serentak telah dibuat dan dalam rencana operasi pengamanan pilkada tersebut telah disusun dengan tata urutan :

1. Dasar

2. Maksud dan tujuan

3. Keadaan

4. Tugas pokok

5. Pelaksanaan

6. Adminstrasi dan logistic

7. Komando dan perhibungan

Penyiapan rencana kontijensi kodim dalam pengamanan pilkada serentak sedang dalam proses penyusunan yang dalam garis besarnya adalah mengenai pengamanan pilkada serentak dengan garis besar meliputi berita personil, kegiatan dan materil.

Dalam penyiapan sistem komando dan pengendalian kodim dalam pengamanan pilkada serentak berdasarkan wawancara dengan Komandan 
Kodim Kolonel Inf Wisnu bahwa: "kodim membuat Posko Pam pilkada serentak di ruang data makodim dan makoramil yang terlibat dalam Pam pilkada serentak Kota Tangerang Selatan”.

Adapun terkait agar supaya kesiapan pirantik lunak yang akan dilaksanakan kodim dalam rangka pilkada serentak dengan baik, perlu adanya kesiapan yang lebih matang dan sinkronisasi dilapangan pada saat dilaksanakannya pengamanan pilkada serentak jelas Dandim.

\section{Soliditas dan Sinergitas Kodim, Polres dan Pemerintah Daerah Dalam Pemberdayaan Wilayah Pertahanan Guna Mengamankan Pilkada Serentak}

Keberadaan komando teritorial TNI AD dianggap berperan penting dalam fungsi pertahanan sekaligus fungsi sosial, politik dan keamanan yang memberikan kemudahan dalam menghadapi konflik eksternal dan internal, menjamin terjalannya hukum, tatanan dan kontrol politik, perbantuan bencana, dan penanganan terorisme. Mengingat besarnya nilai guna Satkowil TNI AD di tengahtengah masyarakat, tugas perbantuan terhadap pemerintah kemudian dicantumkan dalam skema OMSP. Diharapkan pemerintah dapat bekerjasama dengan TNI AD dalam rangka mengakselerasi pencapaian tujuan dari program-program pemerintah.

Kodim 0506/Tangerang sebagai satuan kewilayahan mempunyai tugas pokok menyelenggarakan pembinaan kemampuan, kekuatan dan gelar kekuatan, menyelenggarakan pembinaan teritorial untuk menyiapkan wilayah pertahanan di darat dan menjaga keamanan wilayah dalam rangka mendukung tugas pokok Kodam Jaya. Kodim bertugas pokok menyelenggarakan pembinaan kemampuan, kekuatan dan gelar kekuatan, menyelenggarakan pembinaan teritorial untuk menyiapkan wilayah pertahanan di darat dan menjaga keamanan wilayahnya dalam rangka mendukung tugas pokok Kodam/Korem. Salah satu tugas Kodim dalam melaksanakan perbantuan terhadap pemerintahan daerah adalah memberikan bantuan terhadap pemerintah daerah, perlu dilakukan melalui komunikasi, koordinasi dan kolaborasi dengan pemerintah daerah dan polres serta Lembagalembaga lainnya dan masyarakat sehingga fungsi pengamanan pelaksanaan pilkada guna mengawal pembangunan nasional dapat terwujud dengan optimal. Untuk itu peneliti dalam penelitian ini mengemukakan pembahasan sebagai berikut : 


\section{A. Komunikasi}

Kegiatan yang dilakukan oleh Kodim 0506/Tangerang dalam membantu pemerintah daerah guna menciptakan situasi politik yang kondusif dalam pilkada Kota Tangerang Selatan yaitu bekerjasama dengan berbagai pihak seperti pemerintah daerah (KPU, Bawaslu, Satpol PP) juga dengan Polres Kota Tangerang Selatan. Adapun posisi kodim dalam kerjasama dengan pemerintah daerah yaitu :

a. Melaksanakan komunikasi secara intensif dengan aparat Satpol PP dalam hal keamanan pilkada.

b. Membuat Gugus Kendali/Posko terkait pengamanan pilkada.

c. Melaksanakan latihan bersama penanganan konflik dengan Pemda dan Polres.

d. Terlibat dalam pemberian bantuan pelaksanaan penjagaan di KPU dan Bawaslu.

e. Membuat aplikasi untuk pelaporan setiap permasalahan atau perkembangan situasi sehingga memudahkan masyarakat melaporkan hal-hal menonjol dan memudahkan dalam penanganan permasalahan di wilayah kerja kodim 0506/Tangerang secara cepat dan tepat.

f. Melaksanakan pembongkaran dan pembersihan spanduk kampanye di tempat tempat umum setelah mendapatkan informasi dari Bawaslu dan KPU serta Satpol PP.

g. Melaksanakan operasi dalam menjaga keamanan dan ketertiban di masyarakat setelah mendapatkan informasi dari pemerintah daerah yaitu dari Satpol PP diantaranya ketertiban kampanye dan atribut-atribut kampanye.

Begitu pula posisi kodim dalam bekerjasama dengan Polres Kota Tangerang Selatan, dimana kodim bersama-sama dengan Polres Kota Tangerang Selatan melakukan kegiatan keamanan dan ketertiban pilkada Kota Tangerang Selatan, adapun beberapa kegiatan yang dilakukan oleh Kodim antara lain : 
a. Melaksanakan komunikasi secara intensif dengan Polres Kota Tangerang Selatan dalam hal keamanan dan ketertiban pilkada.

b. Melaksanakan latihan bersama penanganan konflik dengan Polres.

c. Terlibat dalam pemberian bantuan pelaksanaan pilkada bersama-sama Polres Tangerang Selatan.

d. Membuat aplikasi untuk pelaporan setiap permasalahan atau perkembangan situasi sehingga memudahkan masyarakat melaporkan hal-hal menonjol dan memudahkan dalam penanganan permasalahan di wilayah kerja kodim 0506/Tangerang secara cepat dan tepat.

e. Melaksanakan operasi dalam menjaga keamanan dan ketertiban di wilayah Kota Tangerang Selatan bekerjasama dengan Polres.

Berdasarkan hasil wawancara dengan informan kodim terkait komunikasi antara jajaran kodim dengan pemerintah daerah dalam kesiapan pengamanan pilkada serentak, bahwa "komunikasi terlah terjalin dengan baik selama ini baik formal maupun non formal".

Silaturahmi dilakukan antara pimpinan kodim dan pemerintah daerah terutama dalam penyusunan rencana pengamanan pilkada, komunikasi terutama dalam merencanaan kegiatan persiapan pengamanan, mulai dari penyiapan personil, sarana prasarana, adminstrasi sampai dengan logistic dalam pelaksanaan pilkada langsung dilakukan oleh kodim, pemerintah daerah dan polres. Pertemuan dilakukan melalui rapat musyawarah Forkompinda yaitu Walikota, ketua DPRD, Komandan Kodim, dan Kapolres menyusun perencanaan pengamanan pilkada Kota Tamgerang Selatan. Selain pertemuan oleh Forkompinda, kodim dan pemerintah daerah melakukan antara dua belah pihak dalam rangka pembahasan teknis bantuan kodim terhadap pemerintah daerah dalam rangka pelaksanaan pilkada di Kota Tangerang, pertemuan dilakukan baik secara formal dan informal, bahkan komunikasi yang dilakukan tidak saja melalui forum pertemuan diantara kedua belah pihak, namun komunikasi 
dalam rangka tindak lanjut perkembangan dalam pelaksanaan pentahapan pilkada disampaikan oleh pemerintah daerah terutama oleh KPU kepada kodim dalam rangka bantuan pengamanan pilkada. Komunikasi yang dilakukan baik melalui telepon maupun melalui jaringan media social yang selama ini telah dilegalkan menjadi media resmi komunikasi diantara pemerintah daerah dan kodim

\section{B. Koordinasi}

Koordinasi antara jajaran Kodim dengan jajaran Pemda dalam kesiapan pengamanan Pilkada serentak berjalan sangat baik dan intensif dalam kesiapan Pilkada serentak. Rapat kedua belah pihak dilaksanakan secara tertib, dan rutin dijadwalkan oleh Pemda dalam pelaksanaan rapat Forkopimda.

Sesuai hasil wawancara dengan Dandim, Danramil, dan Pasiter Kodim bahwa: "Koordinasi antara Instansi Kodim dan Polres sudah berjalan dengan baik, hal ini dilihat dari adanya pertemuan baik formal dan informal yang dilaksanakan secara rutin oleh kedua belah pihak".

Pertemuan-pertemuan antara pimpinan Kodim dan Polres juga dilaksanakan untuk dapat meningkatkan koordinasi terutama mengenai persiapan pengamanan menghadapi Pilkada di Kota Tangerang Selatan. Hal yang sama juga dikatakan oleh Wakapolres, Kapolsek dan Kanit Bimas bahwa "kordinasi antara instansi Kodim dan polres sudah berjalan dengan baik walau dibawah isu Covid -19 yang sedang melanda".

Walaupun ditengah fenomena Covid - 19 yang mengharuskan mengurangi kegiatan luar rumah namun, tidak ada kendala berarti dalam melaksanakan kordinasi anatara Instansi Kodim dan Polres serta jajaran dibawahnya.

Koordinasi yang baik dari Kodim 0506/Tangerang terlihat dari salah satu kegiatan Kodim 0506/Tangerang ketika menggelar acara kegiatan Gowes dan bakti social yang selalu dilakukan oleh Kodim dan pemerintah daerah. Kegiatan tersebut memperlihatkan berjalannya koordinasi kodim 0506/Tangerang dengan baik saat mengadakan kegiatan yang bersifat 
khalayak ramai di lingkungan pemerintah daerah Kota Tangerang Selatan. Hal yang sama juga dilakukan oleh Kodim 0506/Tangerang dalam berkordinasi secara vertikal kebawah yaitu dengan mengumpulkan seluruh Danramil. Danramil dan Babinsa di Jajaran Kodim 0506/Tangerang berkumpul di Makodim 0506/Tangerang untuk melaksanakan apel Danramil dan Babinsa.

Setelah menguaraikan hasil wawancara mengenai bebrapa kegiatan koordinasi dari Kodim 0506/Tangerang diatas dapat disimpulkan bahwa kordinasi yang dilakukan antara instansi Kodim dengan Polres, Kodim dengan Pemda sudah berjalan baik, serta Kodim pada umumnya adalah kordinasi dilaksanakan dengan baik.

\section{Kolaborasi}

Kolaborasi dalam penyelenggaraan pilkada serentak Kota Tangerang Selatan tahun 2020 dapat berjalan secara baik. Kerjasama berjalan dengan baik, kolaborasi dalam PAM melibatkan kodim dan Linmas, untuk pendanaannya selalu mendapat dukungan penuh dari Pemda. Selain Pemda masalah anggaran selalu dirapatkan dengan DPRD. Ketua DPRD, melalui wawancara menuturkan bahwa:

"kegiatan kolaborasi diantara kodim, pemerintah daerah dan polres yang dilaksanakan sudah dijalankan dengan baik, dan diperkuat dengan adanya silaturahmi melalui kegiatan-kegiatan olahraga bersama maupun acara lain-lain."

Sesuai hasil wawancara dengan Dandim, Danramil, dan Pasiter Kodim bahwa:

"Kolaborasi antara Instansi Kodim dan Polres sudah berjalan dengan baik, dilihat dari adanya kegiatan bersama, aksi bersama, membuat perencanaan kegiatan bersama, yang mendorong ormas dan masyarakat untuk mengurangi potensi pelanggaran dalam penyelenggaraan pilkada serentak di Kota Tangerang Selatan”.

Begitu pula kolaborasi dalam menjalankan atau mengadakan kegiatan pelatihan-pelatihan pengamanan Pilkada serta melakukan sosialisasi Pilkada bersama. Hal yang sama juga dikatakan oleh Wakapolres, Kapolsek dan Kanit Bimas mengenai Kolaborasi diantara 3 
pilar yaitu kodim, polres dan pemerintah daerah sudah berjalan sangat baik terutama dalam kesiapan pengamanan pilkada serentak 2020 di Kota Tangerang Selatan.

Kolaborasi instansi Kodim dan instansi Pemda, telah dilakukan wawancara yang dilakukan dengan Camat, Kakesbangpolinmas, Sekda dan Walikota. Yang menyatakan bahwa kolaborasi yang dilakukan oleh Kodim dan Pemda berjalan dengan baik dengan adanya kegiatan-kegiatan bersama. Kerjasama selalu berjalan dengan sinergis dengan adanya kegiatan bersama dalam bentuk monitoring sebelum pelaksanaan, pelaksanaan dan pasca pelaksanaan. Dilaksanakan penandatanganan pilkada damai pada saat rakor desa dengan peserta forkopimda, muspika dan penyelenggara pemilu. Mengadakan koordinasi dan komunikasi dengan forkopimda, penyelenggara pemilu ditingkat muspika dan desa terkait pengamanan pilkada.

\section{KESIMPULAN}

Kesiapan Kodim 0506/Tangerang dalam pemberdayaan wilayah pertahanan guna mengamankan pilkada serentak, bisa terlihat dari Personil yang berkualitas dan professional dalam bidangnya. Anggaran yang ada sudah cukup memadai meskipun terkadang mendapat sedikit kendala pada saat penyelenggaraannya, yaitu adanya pengeluaran diluar dari anggaran yang sudah diajukan. Sementara Sarana dan Prasarana yang dimiliki oleh Kodim Tangerang dalam kegiatan satuan cukup memadai, namun apabila dikaitkan dengan pengamanan pilkada sarana dan prasarananya masing kurang. Piranti lunak yang sangat memudahkan dalam pemetaan daerah - daerah rawan konflik dan mengancam keberlangsungan Pilkada cukup baik, dimana kodim sudah mampu menyusun perencanaan operasi dan pengendalian dalam pengemanan pilkada serta telah terjalinnya soliditas dan sinergitas diantara 3 pilar yaitu pemerintah daerah, kodim dan polres sehingga dalam penyiapan piranti lunas sudah dapat dilakukan dengan baik dan dengan arus informasi pun berjalan dengan sangat baik.

Soliditas dan Sinergitas Kodim, Polres dan Pemerintah Daerah dalam 
Pemberdayaan Wilayah Pertahanan Guna Mengamankan Pilkada Serentak terjalin sangat baik. Hal ini dapat dilihat dari adanya Komunikasi, Koordinasi, dan Kolaborasi yang sangat baik antara Kodim, Pemda, dan Polres. Komunikasi, Koordinasi, dan Kolaborasi yang sangat baik, baik pada tahap pra pilkada, saat pilkada dan pasca pilkada telah di susun tahapan dan jadwal serta rencana pengamanan pilkada baik oleh masing-masing instansi maupun melalui satgas yang dijalankan Bersama-sama.

Adapun rekomendasi sebagai berikut :

1. Memberikan pelatihan personil yang sudah ada terutama pelatihan pemahaman pilkada serentak.

2. Meningkatnya kualitas dan kuantitas Sarana dan Prasarana yang telah ada.

3. Meningkatkan sinergitas dan solidaritas melalui Komunikasi, Koordinasi dan Kolaborasi yang baik antara Kodim, Polres dan Pemda.

4. Meningkatkan anggaran pilkada dan pengamanan pilkada dan mulai memasukkan kemungkinan pengeluaran tambahan pada saat pemiilihan berlangsung.

5. Memberikan pembelajaran politik bagi masyarakat yang mendorong keberlangsungan pembangunan nasional.

6. Pembaharuan data peta konflik daerah Rawan Fanatisme.

7. Pendataan dan memperketat keamanan terutama bagi Pemilih Non EKTP.

8. Pembaharuan data peta konflik bagi Pengerahan Massa dari luar wilayah Kota Tangerang Selatan.

\section{DAFTAR PUSTAKA}

Agus Pramusinto, 2004, Otonomi Daerah dan Pemilihan Kepala Daerah dalam mencermati Hasil Pemilu 2004, Jakarta (Jakarta: Jurnal Analisis CSIS Vol. 33, No 2 Juni 2004), hlm. 240

Anak Agung Banyu Perwita, Pemberdayaan Wilayah Pertahanan Melalui 
Pembinaan Teritorial Dalam Rangka Pertahanan Negara.(makalah 12) disampaikan dalam Seminar.

Arikunto, S. 2002. Prosedur Penelitian, Suatu Pendekatan Praktek. Jakarta : PT. Rineka Cipta.

Connie Rahakundini Bakrie, Pertahanan Negara dan Postur TNI Ideal, (Jakarta : Yayasan Obor Indonesia, 2007).

Effendy, Onong Unchjana. 2007. Strategi Komunikasi, Sebuah Pengantar Ringkas. Bandung : PT. Remaja Rosdakarya.

Idris - M.Y Tiyas Tinovi, 2014, Kinerja Komisi Pemilihan Umum Daerah dalam Proses Penetapan Daftar Pemilih Tetap (DPT) Pada pemilihan Kepala

Joko J. Prihatmoko, 2005, Pemilihan Kepala Daerah Langsung, Yogyakarta Penerbit Pustaka Pelajar, hlm. 115

Luki Sandra Amalia, Syamsuddin Haris, Sri nur yanti, Lili Romli, Devi Darmawan, Opcit, hlm

Miriam Budiardjo, 2013, Dasar - Dasar Ilmu Politik, Prima Grafika, Jakarta, hlm. 169

Moleong, Lexy J. 2007. Metodologi Penelitian Kualitatif. Bandung : PT. Remaja Rosdakarya.

Muhammad Asfar, 2006, Pemilu dan Perilaku Memilih 1955-2004, Pusat Study Demokrasi dan HAM (PusDeHAM), Surabaya hlm 4-5

Muhammad, Suwarsono. 2013. Strategi Pemerintahan, Manajemen Organisasi Publik. Jakarta : Erlangga.

Ramlan Surbakti, 2008, Sistem pemilu dan tatanan politik demokrasi, dalam ramlan surbakti, dkk (Ed.), Perekayasaan Sistem Pemilu untuk Pembangunan tata politik demokratis, Kemitraan Jakarta, hlm 27 , dalam Luki Sandra Amalia, Syamsuddin Haris, Sri nur yanti, Lili Romli, Devi Darmawan, 2016, Evealuasi Pemilu Legislatif 2014 : Analisi Proses dan Hasil, Pustaka Pelajar, Yogyakarta, hlm 8

Sugiyono. 2012. Memahami Penelitian Kualitatif. Bandung : Alfabeta.

Suradinata, Ernaya. 1996. Organisasi Manajemen Pemerintahan Dalam Era Globalisasi. Jakarta : Gramedia Pustaka Utama.

Syamsyudin Haris, dkk, 1997, Pemilihan Umum di Indonesia : Telaah atas 
Struktur, Proses, dan Fungsi, PPW-LIPI, Jakarta, hlm.6

Tjahjo Kumolo, 2015, Politik Hukum Pilkada Serentak, Expose, Jakarta, hlm.16

\section{Dokumen dan Jurnal :}

Undang-Undang Nomor 3 Tahun 2003 tentang Pertahanan Negara.

Undang-Undang Nomor 4 Tahun 2004 tentang Tentara Nasional Indonesia.

Undang-Undang Nomor 7 Tahun 2017 tentang Pemilu.

Undang - Undang Nomor 7 Tahun 2012 tentang Penanganan Konflik Sosial.

Undang - Undang Nomor 23 tahun 2014 tentang Pemerintahan Daerah.

Undang-Undang Nomor 1 Tahun 2015 tentang Penetapan Peraturan Pemerintah Nomor 1 Tahun 2014 tentang Pemilihan Gubernur, Bupati dan Walikota menjadi Undang-Undang (Lembaran Negara Republik Indonesia Tahun 2015 Nomor 23, Tambahan Lembaran Negara Republik Indonesia Nomor 5656) sebagaimana telah beberapa kali diubah, terakhir dengan UndangUndang Nomor 10 Tahun 2016 tentang Perubahan Kedua atas UndangUndang Nomor 1 Tahun 2015 tentang Penetapan Peraturan Pemerintah Nomor 1 Tahun 2014 tentang Pemilihan Gubernur, Bupati dan Walikota menjadi Undang-Undang (Lembaran Negara Republik Indonesia Tahun 2016 Nomor 130, Tambahan Lembaran Negara Republik Indonesia Nomor 5898).

Peraturan Pemerintah Nomor 2 tahun 2015 tentang Peraturan Pelaksanaan UndangUndang Nomor 7 Tahun 2012 tentang Penanganan Konflik Sosial.

Permenhan RI No. 40 Tahun 2011, tentang Kebijakan Pemberdayaan Wilayah Pertahanan.

Peraturan Pemerintah Republik Indonesia Nomor 9 Tahun 1954 Tentang Penyelenggaraan Undang-Undang Pemilihan Umum;

Peraturan Pemerintah Republik Indonesia Nomor 2 Tahun 2015 Tentang Peraturan Pelaksanaan Undang-Undang Nomor 7 Tahun 2012 Tentang Penanganan Konflik Sosial;

Peraturan Presiden Republik Indonesia Nomor 62 Tahun 2017 Tentang Kedudukan Keuangan Ketua Dan Anggota Badan Pengawas Pemilihan Umum, Ketua Dan Anggota Badan Pengawas Pemilihan Umum Provinsi, Dan Ketua Dan Anggota Dewan Kehormatan Penyelenggara Pemilihan Umum; 
Surat Keputusan KPU Nomor 179/P1.02-Kpt/01/KPU /Iii/2020 Penundaan Tahapan Pemilihan Gubernur Dan Wakil Gubernur, Bupati Dan Wakil Bupati, Dan/Atau Wali Kota Dan Wakil Wali Kota Tahun 2020 Dalam Upaya Pencegahan Penyebaran Covid-19. 